\title{
Sensory evaluation of cookies produced from different blends of wheat and Moringa oleifera leaf flour
}

\author{
Nwakalor, Chizoba N. \\ Department of Food Science and Technology, Federal Polytechnic Oko, Anambra State
}

Email address:

chizobanwakalor@ymail.com

To cite this article:

Nwakalor, Chizoba N.. Sensory Evaluation of Cookies Produced from Different Blends of Wheat and moringa Oleifera Leaf Flour. International Journal of Nutrition and Food Sciences. Vol. 3, No. 4, 2014, pp. 307-310. doi: 10.11648/j.ijnfs.20140304.21

\begin{abstract}
Blends of wheat flour (WF) and Moringa oleifera leaf powder or flour were processed into cookies in the following ratios 100:0,90:10,80:20,70:30,50:50. The sensory evaluation of the cookies samples from the blends was performed. The results of the sensory evaluation showed that there were significant differences in the different attributes that were determined such as in colour, crispiness, taste, flavour and general acceptability. The sensory general acceptability scores showed that the best Moringa flour substitution level for making cookies was $10 \%(90: 10)$ and $20 \%$ (80:20).
\end{abstract}

Keywords: Moringa Leaf Powder, Wheat Flour, Cookies

\section{Introduction}

In most parts of the world, baked goods based on wheat flour alone, are popular food stuffs. The consumption of these products has been consistently in countries like Nigeria (Edema et al.,2005). Wheat as a major source of raw material for the production of these baked products such as cookies also lack some nutrients.

Cookie is a small flat, baked food product usually containing fat, flour, egg and sugar (Pearson 1976). Cookies are mostly baked until crispy or just long enough that they remain soft, but some kind of cookies is not baked at all. Cookies are made in a wide variety of styles by using an array of ingredients including sugar, spices, chocolate, butter, pea-nut butter, nuts or dried frost. Cookies are convenient snack product dried to a very low moisture content taken by young people and adult to provide energy. This is made from dough which is made from a mixture of flour and other ingredients, mixed together into dough which is rested for a period and passed between rollers to make a sheet.

Moringa oleifera, commonly referred to as the drumstick or Ben oil is known for its resistance to drought and diseases and is a tree native to India, but has been planted and naturalized in many other parts of the world, including Nigeria in Africa. It contains 13 species from tropical and subtropical climate that ranges in size from tiny herbs to massive trees. Moringa oleifera is the best known of the 13 (thirteen) species of the genus moringacea (Fabey,2005). Moringa oleifera is also known by many other common names. In Philippines, where the leaves are cooked and fed to babies, it is called 'mother's best friend' or 'mallungay'. Other names include benzolive tree in Haiti, horse radish tree in Florida and 'nebeday', which means "never die" in Senegal (Price, 2000). In Nigeria, it is known as 'Zogale' in Hausa, 'Okwe Oyibo' in Igbo, 'Ewe Ile' in Yoruba and 'Jeghel-agede' in Tiv.

Moringa oleifera is an important food commodity which has had enormous attention as the "natural nutrition of the tropics'. The leaves, seeds and flowers of Moringa oleifera all have great nutritional and therapeutic value (Olushola, 2006). The seeds are eaten like peas or roasted like nuts when still green; the dry seeds are apparently not used for human consumption, perhaps because the bitter coating becomes hardened while the flowers are eaten when cooked and taste like mushrooms (Price, 2000). The leaves are outstanding as a source of vitamins A, B group and (C when raw) and are among the best sources of minerals. They are also excellent sources of protein, but poor sources of carbohydrate and fat. Moringa leaves are one of the best plant foods available in nature (Price,2000; Olushola, 2006).

The leaves can be cooked and eaten as a vegetable -like spinach. More often, they are dried and ground into flour and used in soups and sauces. They are especially 
beneficial in the treatment of many ailments, due to their various medicinal properties and rich iron content (Olushola, 2006).

In Africa, nursing mothers have been shown to produce much more milk when they add Moringa leaves to their diet. Severely malnourished children were reported to have made significant weight gains when care givers add the leaves to their diet to increase its nutritional content (Price,2000; Fuglie, 2001).

Moringa oleifera is esteemed as a versatile plant due to its multiple uses. Its leaves are good source of protein, vitamins $\mathrm{A}, \mathrm{B}$ and $\mathrm{C}$ and minerals such as calcium and iron (Dahot, 1988). Moringa leaves are more potent in nutritional values. Its vitamin $\mathrm{C}$ content is seven (7) times more than that of oranges, it has thirteen (13) times more vitamin than spinach and is on a lead on its own when it comes to amino acid, 2,000 times more than green tea and 242 times more than apples. The leaves are sources of the sulphur containing amino acid such as methionine and cystine which are often in short supply in most legumes (Martin et al., 1998).It is also a good source of good cholesterol, high density lipoprotein which in high levels is known to protect against cardiovascular disease. Breast feeding mothers can also greatly benefit from fresh Moringa leaves as they are known to increase the volume of milk. Moringa leaves are completely safe for consumption because they have no known negative side effect, nor toxic elements. For centuries, people in many countries have used Moringa leaves as traditional medicine for common ailments. They are traditionally used for the cure of asthma, catarrh, chest congestion, cholera, conjunctivitis, cough, diarrhea, eye and ear infections, fever, headaches, abnormal blood pressure, scurvy, semen deficiency, sore throat, tuberculosis etc. Moringa is said to cure about 300 diseases and almost have all the vitamins found in fruits and vegetables. Moringa is considered to be the most nutritious, rich plant on earth. Moringa leaves have been consumed by Asian people for millennia as a healthy food products. Containing more than 90 nutrients and 46 anti-oxidants, these vivid green leaves are natural super -power food. Moringa was highly valued and Egyptians extracted edible perfume and skin lotion. In the $19^{\text {th }}$ century, plantation of Moringa in the West Indies exported the oil to Europe for perfumes and lubricants for machinery.

In developing countries, Moringa has the potential to improve nutrients, boost food security, foster rural development and support sustainable landmark. Some of the benefits of Moringa includes the following:

- It increases the natural defenses of the body

- Provides nourishment to the eye and the brain

- $\quad$ Promotes metabolism with bio-available ingredients

- Promotes the cell structure of the body

- Promotes natural serum cholesterol

- Lowers the appearance of wrinkles and fine lines.

- Promotes the normal functioning of the liver and kidney

- It beautifies the skin
- $\quad$ Promotes energy

- Promotes proper digestion

- Acts as an antioxidants

- Takes care of the immune system of the body

- $\quad$ Promotes health circulatory system

- It promotes general wellness

- Supports the normal sugar level of the body.

In this study, the effect of substituting wheat flour with Moringa leaf flour on the sensory evaluation of cookies was determined.

\section{Materials and Methods}

The Moringa leaves used in this study were collected from a farmer's compound in Ndiowu community in Orumba North Local Government Area of Anambra State while the wheat flour (honey well), baking powder, fat (margarine), granulated sugar, eggs and salt were purchased from Eke Ekwulobia market in Ekwulobia town of Anambra State, Nigeria.

They were taken to the laboratory for processing. All the used materials (pan and baking oven) were from Food Technology department of the Federal Polytechnic Oko, Anambra State, Nigeria.

\subsection{Processing of Moringa Leaves Into Flour}

The fresh Moringa leaves were separated from the stalks of the ties, it was then removed from the leaf petal by hand. The leaves were placed on a bag spread on a laboratory table for drying.

\subsection{Drying}

The Moringa leaves were dried under a room temperature for 16 days. The leaves were turned over several times with hand to improve uniform drying at room temperature.

\subsection{Milling}

The dried leaves were milled using a stainless steel harmer's mill. After milling, it was sieved to get the Moringa flour or powder.

\subsection{Baking Process}

The five blends of wheat/Moringa flours used were different ratios such as 100:0; 90:10;80:20; 70:30 and 50:50 for cookies preparations.

\section{Recipe for Cookies Formulation}

\begin{tabular}{llllll}
\hline Ingredients & \multicolumn{5}{l}{ Ratio (gramme) } \\
\hline & $100: 0$ & $70: 30$ & $80: 20$ & $90: 10$ & $50: 50$ \\
Moringa flour & 0 & 30 & 20 & 10 & 50 \\
Wheat flour & 100 & 70 & 80 & 90 & 50 \\
Fat & 55 & 55 & 55 & 55 & 55 \\
Sugar & 45 & 45 & 45 & 45 & 45 \\
Salt & 1 & 1 & 1 & 1 & 1 \\
\hline
\end{tabular}




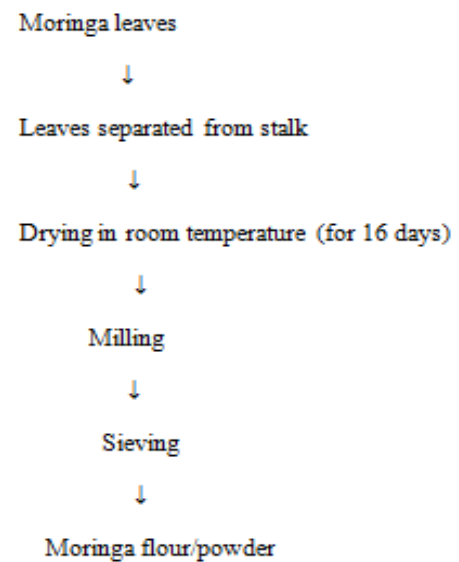

Figure 1. flow chart for the production of Moringa flour.

\subsection{Flour Blending and Cookies Production}

The Moringa leaves flour were blended with wheat flour at various proportions of 70:30, 80:20, 90:10, 50:50 and 100:0 as control. The measurements were carefully weighed. The measured quantities of shortening (fat and milk) and granulated sugar were mixed well in a rubber bow to a creamy consistency. The wheat flour and Moringa flour blends, baking powder and salt were mixed together. This was then added to the creamy mixture and kneaded until a dough of plastic but not sticky consistency was obtained. Kneading continued for 5 mins to obtain a smooth, plastic dough. The dough was rolled out on a rolling pin and the desired shapes was given to the cut out dough. The cookies was baked, allowed to cool and packaged well.

\subsection{Sensory Evaluation}

10 panelists made up of males and females were selected from the department of Food Science and Technology of Federal Polytechnic Oko, Anambra State, Nigeria. The panelists were educated on testing terminologies and requested to evaluate the various cookies samples for colour, crispiness, taste, flavour and general acceptability using a 9-point Hedonic scale where 9 was equivalent to like extremely and 1 meant dislike extremely as described by Ihekoronye and Ngoddy (1985). The samples were presented in a well packaged material, coded with different random alphabets. It was served simultaneously to ease possibility of panelist evaluating the sample. Necessary precautions were taken to prevent bias of panelist. They were given a sachet of water to rinse their mouth after each stage of sensory evaluation and by ensuring that the panelists were ignorant of the actual sample represented by a code.

The sensory evaluation data were analyzed using analysis of variance (ANOVA) as described by Iwe (2002).

\section{Results and Discussion}

The sensory results (Table 1) indicated that acceptable cookies that were not distinguished from the control for the most of the sensory properties were made from $10 \%$ and $20 \%$ substitution of Moringa flour for cookies samples respectively. The acceptability of the cookies produced decreased as the level of the Moringa flour increased as indicated by most of the sensory properties.

Table 1. mean sensory scores of cookies prepared from blends of wheat flour and Moringa flour.

\begin{tabular}{llllll}
\hline $\begin{array}{l}\text { Sample } \\
\text { code }\end{array}$ & colour & crispy & taste & flavour & $\begin{array}{l}\text { general } \\
\text { acceptability }\end{array}$ \\
\hline $\mathrm{WFC}$ & $7.6^{\mathrm{a}}$ & $7.7^{\mathrm{a}}$ & $7.6^{\mathrm{a}}$ & $7.2^{\mathrm{a}}$ & $7.7^{\mathrm{a}}$ \\
$\mathrm{WMC}_{1}$ & $5.4^{\mathrm{a}}$ & $6.0^{\mathrm{a}}$ & $6.3^{\mathrm{a}}$ & $5.1^{\mathrm{a}}$ & $6.0^{\mathrm{a}}$ \\
$\mathrm{WMC}_{2}$ & $4.9^{\mathrm{b}}$ & $5.5^{\mathrm{a}}$ & $5.0^{\mathrm{a}}$ & $3.9^{\mathrm{b}}$ & $4.5^{\mathrm{a}}$ \\
$\mathrm{WMC}_{3}$ & $3.4^{\mathrm{b}}$ & $5.0^{\mathrm{b}}$ & $4.3^{\mathrm{b}}$ & $3.3^{\mathrm{b}}$ & $3.9^{\mathrm{b}}$ \\
$\mathrm{WMC}_{4}$ & $3.3^{\mathrm{b}}$ & $5.1^{\mathrm{b}}$ & $3.3^{\mathrm{b}}$ & $3.3^{\mathrm{b}}$ & $3.3^{\mathrm{b}}$ \\
\hline
\end{tabular}

Means not followed by the same superscript in a row are significantly different $(\mathrm{P}<0.05)$

WFC: $100 \%$ wheat flour cookies

$\mathrm{WMC}_{1}: 90 \%$ wheat flour and $10 \%$ Moringa flour $\mathrm{WMC}_{2}: 80 \%$ wheat flour and $20 \%$ Moringa flour $\mathrm{WMC}_{3}: 70 \%$ wheat flour and 30\% Moringa flour $\mathrm{WMC}_{4}: 50 \%$ wheat flour and 50\% Moringa flour

\section{Conclusion}

The result from the study showed that the use of wheat flour and Moringa flour in the ratio 90:10 (90g of wheat flour and $10 \mathrm{~g}$ of Moringa flour) for the production of cookies showed a positive result and was approved to be the best in all sensory attributes by the panelists.

Cookies of acceptable sensory attributes were produced with up to $10 \%$ and $20 \%$ of Moringa flour respectively. This present study shows that there exists potential for Moringa flour incorporation into baked products. This would be of economic importance in many developing countries such as Nigeria in promoting the utilization of Moringa.

\section{Recommendation}

I recommend the use of Moringa flour in the production of cookies because of its health benefits. Cookies industries in Nigeria should use Moringa flour in the appropriate ratio, I recommend the use of the ratio 90:10 in the production because it was the best accepted sample in all sensory attributes.

\section{References}

[1] Dahot, M.U. (1988). Vitamin Contents of the Flowers and Seeds of Moringa oleifera. Pakistan J. Biochemistry 21: 2124.

[2] Edema, M.O., Sanni, L.O. and Sanni, A.L.(2005). Evaluation of maize -soybean flour blends for soy-maize bread production in Nigeria. African Journal of Biotechnology 4:911-918. 
[3] Fabey, J.W.(2005). Moringa oleifera : A review of the medical evidence for the nutritional therapeutic and prophylactic properties. Macmillan publishers, London. pp 116-120.

[4] Fuglie, L.J.(2001). The Miracle Tree: the multiple attributes of Moringa. Church world service, west African regional office, Dakar, Senegal. Pp 103-136.

[5] Ihekoronye, A.I. and Ngoddy, P.O.(1985). Integrated Food Science and Technology for theTropics. Macmillan Publishers Ltd., pp.180-181,189.

[6] Iwe, M.O. (2002). Handbook of Sensory methods and Analysis. Rojoint CommunicationServices Ltd., pp51-62.
[7] Martin, F.W., Ruberte, R.M. and Meitzner, L.S. (1998). Edible leaves of the tropics. $3^{\text {rd }}$ Ed. Educational concerns for hunger organization, Inc., N.ft. Meyers, Fl. 194pp.

[8] Olushola, A.T.E.(2006). "The Miracle tree", Moringa oleifera (Drumstick). In : Achieve vibrant health with nature, keep hope alive series 1, Unijos consultancy limited press, Jos, Nigeria. Pp 120-136.

[9] Price, L.L.(2000). The Moringa tree. www.echonet.org. Accessed on 14/11/2010. 